\title{
A Mini Review: Efek Farmakologi Andrographis Paniculata (Sambiloto)
}

\author{
Putu Nita Cahyawati $1^{*}$ \\ ${ }^{1}$ Bagian Farmakologi dan Farmasi Fakultas Kedokteran dan Ilmu Kesehatan, Universitas Warmadewa \\ *putunitacahyawati@gmail.com
}

\begin{abstract}
Abstrak
Andrographis paniculata (A. paniculata) atau sambiloto merupakan salah satu tanaman herbal yang pemanfaatannya cukup luas di masyarakat. Tumbuhan ini tumbuh baik di wilayah Asia Tenggara dan dilaporkan memiliki berbagai efek farmakologi bagi kesehatan. $A$. paniculata diketahui memiliki efek antikanker, antibakteri, analgetik, antidiabetik dan menurunkan tekanan darah. Akan tetapi, semua hasil penelitian ini masih terbatas pada pengujian pada hewan coba dan belum ada uji klinis yang memadai pada manusia. Data efek tanaman ini pada kesehatan reproduksi juga menunjukkan bahwa tanaman ini dapat mengganggu proses spermatogenesis sehingga dapat mengganggu kesuburan.
\end{abstract}

Kata kunci: Andrographis paniculata, A. Paniculata, sambiloto, efek farmakologi

\section{Pendahuluan}

Andrographis paniculata (A. paniculata) atau sambiloto, umumnya dikenal sebagai 'King of Bitter, adalah tanaman kecil, tahunan, dan bercabang yang tergolog dalam keluarga Acanthaceae. Tanaman ini banyak tumbuh di Asia Tenggara termasuk India, Sri Lanka, Jawa, Pakistan, Indonesia dan Malaysia. Secara tradisional, A. paniculata secara luas digunakan dalam pengobatan Ayurveda, Unani dan Siddha untuk pengobatan berbagai penyakit. ${ }^{1}$ A. paniculata dilaporkan memiliki efek hepatoprotektor, antimalaria, antihipertensi, antipiretik, antitrombolitik, dan antidot untuk gigitan ular. $^{2}$ Kajian pustaka ini bertujuan memberikan gambaran tentang beberapa efek farmakologi $A$. paniculata berdasarkan hasil-hasil penelitian sebelumnya.

\section{a. Efek Antikanker}

A. paniculata dilaporkan memiliki efek antikanker yang sangat signifikan sehingga memiliki potensi terapeutik untuk mencegah penyakit keganasan. Ekstrak hidroalkohol A. paniculata dilaporkan paling efektif untuk menghambat pertumbuhan ovary cancer cell line (ovcar5) dengan kemampuan penghambatan sebesar $\quad 51.12 \% .^{3} \quad$ Andrographolide, komponen yang diekstrak dari $A$. paniculata terbukti mampu menghambat pertumbuhan sel kanker dan menginduksi apoptosis. Andrographolide terbukti menunjukan efek antiproliferatif pada sel 
leukimia myeloid akut U937. Pemberiannya pada awal pengobatan Topotecan (suatu obat yang berfungsi sebagai inhibitor topoisomerase I dengan risiko efek samping yang signifikan) terbukti memiliki efek sinergis, sehingga dosis Topocetan yang digunakan menjadi lebih rendah. $^{4}$ Andrographolide juga dapat menghambat migrasi dan invasi sel cholangiocarcinoma (CCA) dengan cara mensupresi ekspresi claudin-1 melalui aktifasi jalur sinyal p-38 MAPK. ${ }^{5}$ Efek antikanker ini kemungkinan disebabkan adanya kandungan flavonoids, alkaloids, polyphenols yang mampu menghambat sintesis protein melalui penghancuran DNA atau melalui penghambatan pada level translasi sehingga menyebabkan kematian sel kanker. ${ }^{3}$

Hasil studi in vitro lainnya yang menilai tentang daun $A$. paniculata juga menemukan hasil yang serupa. $A$. paniculata menunjukkan aktifitas antikanker yang sangat baik pada cell line kanker dengan menggunakan metode Spectrophotometric MTT assay. Ekstrak etanol menunjukkan $\mathrm{IC}_{50}$ hampir mendekati 50\% pada cell line neuroblastoma (IMR-32) dan human colon (HT-29) pada konsentrasi $200 \mu \mathrm{g} / \mathrm{ml}$. Kemampuan penghambatan ini dikaitkan dengan adanya alkaloid dan flavonoid yang terkandung pada tanaman ini. Dengan demikan, tanaman ini dapat diganakan sebagai alternatif pengobatan kanker yang dapat mencegah timbulnya efek samping pengobatan kemoterapi. ${ }^{6}$

\section{b. Efek Antibakteri}

Ektrak etanol $A$. paniculata dilaporkan dapat menghambat pertumbuhan bakteri baik gram negatif maupun gram positif. ${ }^{2}$ Hasil penelitian lainnya menunjukkan bahwa pada semua dosis ekstrak kloroform dan metanol A. Paniculata secara potensial menghambat pertumbuhan semua patogen yang diperiksa kecuali Pseudomonas aeruginosa. Seluruh patogen tersebut antara lain Escherichia coli, Aeromonas hydrophila, Proteus vulgaris, Pseudomonas aeruginosa, Staphylococcus aureus, Streptococcus pyogenes, Bacillus subtilis, Klebsiella pneumonia and Salmonella typhi. ${ }^{1}$ Ektrak air A. paniculata menunjukan aktivitas antimikrobia yang signifikan kemungkinan akibat adanya kandungan protein arabinogalactan dan andrographolides.7

\section{c. Efek Antidiabetes}

Hasil penelitian menunjukkan bahwa ekstrak etanol A. paniculata dapat menurunkan kadar gula darah sebesar $46.21 \%$, pada tikus yang diinduksi aloksan dibandingkan dengan kelompok kontrol. ${ }^{8}$ Pemberian A. paniculata selama 5 hari mampu menurunkan kadar gula darah, kadar trigliserida dan LDL, namun tidak mempengaruhi kadar kolesterol pada model hewan tinggi lemak. Hasil ini menunjukkan bahwa A. paniculata memiliki efek hipoglikemia dan hipolipidemia, walaupun mekanisme pastinya belum diketahui. ${ }^{9}$ Pengobatan 200mg/kgBW ekstrak daun $A$. 
https://ejournal.warmadewa.ac.id/index.php/wicaksana

paniculata cukup efektif untuk memperbaiki profil metabolik pada hewan uji. ${ }^{10}$

\section{d. Efek pada Tekanan Darah}

Ekstrak etanol A. paniculata memiliki aktivitas antihipertensi yang poten pada phenylephrine-induced hypertensive rats. Pada model tersebut $A$. paniculata mampu menurunkan tekanan darah sistolik lebih dari $120 \%$ dan diastolik lebih dari $150 \%$. Tekanan darah tinggi diinduksi menggunakan alpha adrenergic receptor agonist, phenylephrine (0.9 $\mathrm{mg} / \mathrm{kgBW})$. Pengukuran tekanan darah dilakukan sebanyak 3 kali (sebelum induksi, 15 menit dan 45 menit setelah pemberian phenylephrine) dan diukur menggunakan CODA Non Invasive Blood Pressure (NIBP). ${ }^{11}$

Ekstrak air $A$. paniculata dapat menurunkan tekanan darah sistolik pada spontaneously hypertensive rats (SHR), kemungkinan melalui akibat penuruanan kadar angiotensinconverting enzyme (ACE) dalam plasma dan penurunan kadar radikal bebas di ginjal. ${ }^{12}$

Terdapat 3 komponen aktif diterpenoid yang diisoloasi dari A. paniculata, yaitu andrographolide (AP1), 14-deoxy-11,12didehydroandrographolide (AP3) dan neoandrographolide (AP4). AP3 dilaporkan memiliki efek hipotensif dan vasorelaksan yang paling poten. Sel otot polos pembuluh darah merupakan tempat utama kerja hingga bisa menimbulkan efek hipotensi tersebut. ${ }^{13}$ andrographolide juga dapat menghambat aktivasi ERK1/2, p38MAPK, dan NF-KB yang diinduksi oleh ox-LDL. Penghambatan pada jalur ini kemungkinan menjadi salah satu penyebab terhambatnya pembentukan plak aterosklerosis pada pembuluh darah. Aterosklerosis terjadi akibat adanya inflamasi kronis dan progresif pada pembuluh darah. ${ }^{14}$

\section{e. Efek Analgesik dan Antiinflamasi}

Efek analgesik dinilai menggunakan hot plate dan writhing tests. Hasil menunjukkan bahwa pada dosis $4 \mathrm{mg} / \mathrm{kg}$ semua subtrat menunjukkan efek analgetik dan peningkatan doosis tidak meningkatkan efek analgesiknya. Diantara seluruh derivat andrographolide, 3,19isopropylidenyl- derivatives dan 3,19dipalmitoyl-derivative menunjukkan potensi yang paling tinggi sebagai agen analgetik, antipiretik dan antiiflamasi. ${ }^{15}$ Kombinasi ekstrak daun A. paniculata (100, 200 dan 400 $\mathrm{mg} / \mathrm{kg} / \mathrm{hr}$, p.o.), dan andrographolide (30, 60 and $120 \mathrm{mg} / \mathrm{kg} / \mathrm{hr}$, p.o.) juga menunjukkan aktivitas analgesik dan antiinflamasi pada model hewan diabetes. Kandungan andrographolide dipercaya menjadi penyebab timbulnya efek tersebut. ${ }^{16}$

Pemberian ekstrak A. paniculata secara oral menunjukkan efek antiinflamasi yang sangat signifikan pada pathogen-induced PID rat. Efek antiinflamasi ditunjukkan melalui penekanan pada infiltrasi sel neutrofil dan limfosit, penurunan produksi sitokin dan kemokin. Mekanisme yang dipercaya

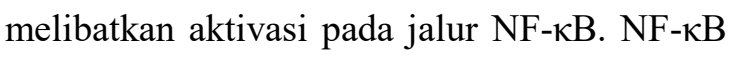
merupakan suatu kompleks protein yang pada keadaan istirahat akan berikatan kovalen dengan IкB yang terletak pada sitoplasma sel. 
Saat TLR pada permukaan sel mengenali patogen, akan terjadi fosforilasi dan degradasi

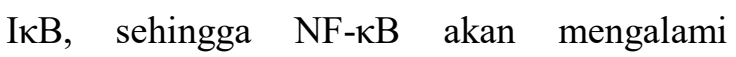
translokasi ke nukleus dan berikatan dengan cis-acting $N F-\kappa B$ enhancer element, sehingga memicu ekspresi mediator proinflamasi seperti IL-1 $\beta$ dan IL-6. ${ }^{17}$

\section{f. Efek Terhadap Kesehatan Reproduksi}

Kandungan andrographolide pada $A$ paniculata dapat mengganggu maturasi meiosis oosit mencit melalui penghambatan pada reorganisasi sitoskleton, sehingga dapat menimbulkan efek samping pada fertilitas atau kesuburan wanita. ${ }^{18}$ Studi lain juga mendukung hasil temuan ini. Andrographolide dilaporkan bersifat toksik terhadap reproduksi laki-laki, sehingga disarankan untuk digunakan sebagai kontrasepsi pada laki-laki. Studi pada hewan coba selama 48 hari menunjukkan terjadinya abnormalitas hasil analisis sperma yang meliputi gangguan motalitas, jumlah sel sperma, gangguan bentuk sperma, abnormalitas kauda epididimal spermatozoa, dan gangguan pada gambaran histopatologi testis. Andrographolide kemungkinan mengganggu proses spermatogenesis melalui hambatan sitokinesis pada proses pembelahan sel line spermatogenik. ${ }^{19}$

Hasil penelitian ini berbanding terbalik dengan studi lainnya yang menemukan bahwa tidak ditemukan adanya efek samping ekstrak $A$ paniculata $(1000 \mathrm{mg} / \mathrm{kg} / \mathrm{hr})$ terhadap level testosteron dan tingkat kesuburan pada hewan coba. Total sperma dan motilitas sperma juga tidak terpengaruh. Testis dan epididimis tidak menunjuukkan perubahan histopatologi yang bermakna. $^{20}$

\section{Kesimpulan}

Berdasarkan hasil telaah pustaka, $A$. paniculata diketahui memiliki efek antikanker, antibakteri, analgetik, antidiabetik dan menurunkan tekanan darah. Akan tetapi, semua hasil penelitian ini masih terbatas pada pengujian pada hewan coba dan belum ada uji klinis yang memadai pada manusia. Akibatnya efek pasti tanaman ini pada manusia belum diketahui. Data efek tanaman ini pada kesehatan reproduksi juga menunjukkan bahwa tanaman ini dapat mengganggu proses spermatogenesis sehingga dapat mengganggu kesuburan. Oleh karenanya, penelitian lebih lanjut perlu dilakukan sebelum tanaman ini dipergunakan secara luas.

Referensi:

1. Geetha I, Catherine P, Alexander S. Antibacterial activity of Andrographis paniculata extracts. The Pharma Innovation Journal. 2017. 6(5): 01-04

2. Mishra US, Mishra A, Kumari R, Murthy PN, Naik BS. Antibacterial Activity of Andrographis paniculata. Indian J Pharm Sci. 2009. 71(4): 436438.

3. Singh S, Mehta A, Baweja S, Ahirwal L, Mehta P. Anticancer Activity of Andrographis paniculata and Silybum marianum on 
Five Human Cancer Cell Lines. Journal of Pharmacology and Toxicology. 2013. 8:42-48.

4. Hodroj MH, Jardaly A, Raad SA, Zouein A, Rizk S. Andrographolide potentiates the antitumor effect of topotecan in acute myeloid leukemia cells through an intrinsic apoptotic pathway. Cancer Management and Research. 2018.10: 1079-1088

5. Phorutai P, Supeecha K, Seiji O, Tavan J. Andrographolide Inhibits Cholangiocarcinoma Cell Migration by Down-Regulation of Claudin-1 via the p-38 Signaling Pathway. Frontiers in Pharmacology. 2019. 10: 827 doi.org/10.3389/fphar.2019.00827

6. Rajeshkumar $\mathrm{S}$, Nagalingam $\mathrm{M}$, Ponnanikajamideen $M$, Vanaja $M$, Malarkodi C. Anticancer Activity Of Andrographis Paniculata Leaves Extract Against Neuroblastima (IMR32) And Human Colon (HT-29) Cancer Cell Line. World Journal of Pharmacy and Pharmaceutical Sciences.2015. 4(6):1667-1675

7. Singha PK, Roy S, Dey S. Antimicrobial activity of Andrographis paniculata. Fitoterapia. 2003. 74(78):692-4

8. Roy BK, Ahmed K, Chowdhury AMS, Sarwaruddin, Rashid MA. Antidiabetic Activity of Andrographis paniculata. Dhaka University Journal of Pharmaceutical Sciences. 2007. 6.10.3329/dujps.v6i1.338.
9. Nugroho AE, Andrie M, Warditiani NK, Siswanto E, Pramono S, Lukitaningsih E. Antidiabetic and antihiperlipidemic effect of Andrographis paniculata (Burm. f.) Nees and andrographolide in highfructose-fat-fed rats. Indian $\mathrm{J}$ Pharmacol. 2012. 44(3): 377-381.

10. Akhtar MT, Bin Mohd Sarib MS, Ismail IS, Abas F, Ismail A, Lajis $\mathrm{NH}$, et al., Anti-Diabetic Activity and Metabolic Changes Induced by Andrographis paniculata Plant Extract in Obese Diabetic Rats. Molecules. 2016. 21(8):1026.

11. Trilestari, Nurrochmad A, Ismiyati, Wijayanti A, Nugroho AE. Antihypertensive activity of ethanolic extract of Andrographis paniculata herbs in wistar rats with a non-invasive method. 2015. 7:247-255.

12. Zhang CY, Tan BK. Hypotensive activity of aqueous extract of Andrographis paniculata in rats. Clin Exp Pharmacol Physiol.1996 Aug;23(8):675-8.

13. Yoopan N, Thisoda P, Rangkadilok N, Sahasitiwat S, Pholphana N, Ruchirawat $\mathrm{S}$, et al., Cardiovascular Effects of 14-Deoxy-11,12didehydroandrographolide and Andrographis paniculata Extracts. Planta medica. 2007. 73:503-11.

14. Xing LF, Sheng LS. Effects of andrographolide on the activation of mitogen activated protein kinases and 
https://ejournal.warmadewa.ac.id/index.php/wicaksana

nuclear factor- $\mathrm{kB}$ in mouse peritoneal macrophage-derived foam cells. Chinese Journal of Integrative Medicine. 2012. 18(5):391-394

15. Suebsasana S, Pongnaratorn P, Sattayasai J, Arkaravichien T, Tiamkao S, Aromdee C. Analgesic, antipyretic, anti-inflammatory and toxic effects of andrographolide derivatives in experimental animals. Arch Pharm Res. 2009.32(9):1191200.

16. Thakur DA, Rai G, Chatterjee S, Kumar V. Analgesic and antiinflammatory activity of Andrographis paniculata and andrographolide in diabetic rodents. EC Pharmaceutical Science. 2015. 1. 19-28.

17. Zou W, Xiao Z, Wen X, Luo J, Chen $\mathrm{S}$, Cheng $\mathrm{Z}$, et al., The antiinflammatory effect of Andrographis paniculata (Burm. f.) Nees on pelvic inflammatory disease in rats through down-regulation of the NF- $\kappa B$ pathway. BMC Complement Altern Med. 2016. 16: 483.

18. Liang HX, Lu SS, Yan Z, Kuang YP, Zhu XX, Yan ZG, et al., Andrographolide disrupts meiotic maturation by blocking cytoskeletal reorganisation and decreases the fertilisation potential of mouse oocytes. Reproduction, Fertility and Development.2017. 29(12) 2336-2344

19. Akbarsha MA, Murugaian P. Aspects of the male reproductive toxicity/male antifertility property of andrographolide in albino rats: effect on the testis and the cauda epididymidal spermatozoa. Phytotherapy Research. 2000. 14(6): 432-435

20. Allan JJ, Pore MP, Deepak M, Murali B, Mayachari AS, Agarwal A. Reproductive and fertility effects of an extract of Andrographis paniculata in male Wistar rats. Int J Toxicol. 2009. 28(4):308-17. 